\title{
DEBIUTY
}

\section{BARTOSZ JANIK}

\section{Prace pogłębiarskie - analiza możliwości wykorzystania ubezpieczenia jako narzędzia zabezpieczenia interesów stron kontraktu}

Jednym z najważniejszych elementów podtrzymania konkurencyjności polskich portów jest stała realizacja przedsięwzięć poprawiajacych dostęp do portu od strony morza. Do takich przedsięwzięć można zaliczyć modernizację i pogłębianie torów wodnych, umacnianie ich brzegów oraz rozbudowę falochronów zewnętrznych. Kluczowym elementem każdej z tych inwestycji sq roboty pogłębiarskie. Polegaja one na hydraulicznym lub mechanicznym odspojeniu gruntu z dna, wyniesieniu go ponad powierzchnię wody i przetransportowaniu tak uzyskanego urobku na miejsce odkładu. Czynności te odbywaja się przy wykorzystaniu specjalistycznejfloty pływajacej. Z punktu widzenia problematyki ubezpieczeniowejjest to bardzo ciekawe zagadnienie, łaczqce w sobie ryzyko morskie oraz wynikajqce z prowadzenia inwestycji budowlanej. Przedmiotem rozważań w poniższym artykule jest kwestia określenia realnego pokrycia ubezpieczeniowego, jakim może dysponować wykonawca, oraz wskazanie luk w ochronie ubezpieczeniowej. Przeprowadzona ocena adekwatności dostępnej ochrony do potrzeb może stanowić wstęp do prac nad stworzeniem optymalnej oferty ubezpieczeniowej dla omawianych inwestycji oraz dostarczyć podstaw wiedzy do formułowania wymogów ubezpieczeniowych w dokumentacji przetargowej.

Słowa kluczowe: prace pogłębiarskie, ubezpieczenie, ubezpieczenia morskie, ryzyko budowy, przetarg publiczny, modernizacja torów wodnych, polskie porty.

\section{Zapotrzebowanie na prace pogłębiarskie w Polsce}

Podstawowymi punktami umożliwiającymi korzystanie z dostępu do morza sa porty. Obecnie na polskim wybrzeżu funkcjonuje 46 przystani morskich oraz 33 porty morskie, ${ }^{1} \mathrm{z}$ czego czterem

1. Polityka morska Rzeczypospolitej Polskiej do roku 2020 (z perspektywq do 2030 roku), Warszawa 2015, https://mgm.gov.pl/wp-content/uploads/2016/01/Polityka-morska-Rzeczypospolitej-Polskiej_uchw._Nr_33_ RM_z_17_03_2015.pdf [dostęp: 10.08.2017], s. 15. 
(Gdańsk, Gdynia, Szczecin, Świnoujście) ustawowo zostałnadany status portów o podstawowym znaczeniu dla gospodarki narodowej ${ }^{2}$. Dla zapewnienia ich prawidłowego funkcjonowania szczególnie ważnym zagadnieniem jest utrzymanie dobrego stanu infrastruktury dostępowej oraz odpowiedniej głębokości red, torów wodnych i basenów portowych. Dotychczas działalność państwa w tym obszarze opierała się ramowo o Program rozwoju polskich portów morskich do 2020 roku, realizujący cele zawarte w Strategii Rozwoju Kraju 2020, przyjętej uchwałą Rady Ministrów w dniu 25 września 2012 roku. Aktualna władza za obowiązujący w tej materii dokument wskazuje wdrożoną uchwałą Rady Ministrów z 2007 roku Strategię rozwoju portów morskich do 2015 roku do czasu zastapienia jej dopiero co opracowywanym Programem rozwoju polskich portów morskich ${ }^{4}$.

Za główny cel Programu rozwoju polskich portów do 2020 roku, opracowanego przez ówczesne Ministerstwo Transportu, Budownictwa i Gospodarki Morskiej, przyjęto poprawę konkurencyjności polskich portów morskich oraz wzrost ich udziału w rozwoju społeczno-gospodarczym kraju i podniesienie rangi portów morskich w międzynarodowej sieci transportowej ${ }^{5}$. Cel ten opiera się na dwóch celach szczegółowych, tj. na dostosowaniu oferty usługowej portów morskich do zmieniajacych się potrzeb rynkowych (pierwszy cel szczegółowy) i na stworzeniu bezpiecznego oraz przyjaznego dla środowiska systemu portowego (drugi cel szczegółowy), do których z kolei przypisano zadania inwestycyjne ${ }^{6}$. Za najważniejsze zadanie inwestycyjne uznano dostosowanie parametrów infrastruktury portowej oraz infrastruktury dostępu do portów morskich od strony morza do obsługi większych statków niż te dotychczas obsługiwane?. Konieczność taka jest uzasadniana stałym wzrostem wielkości jednostek pływających korzystających z morskich portów handlowych, na potwierdzenie czego przywołany został raport Konferencji Narodów Zjednoczonych ds. Handlu i Rozwoju Review of Maritime Transport 2012, ${ }^{8}$ z którego można odczytać, że wielkość mierzona w TEU ${ }^{9}$ jednostek pływających stale wzrasta. W 1987 roku średnia wielkość statku handlowego wynosiła 1155 TEU, dwadzieścia lat później w 2007 już 2417 TEU natomiast na początku roku 2012, w którym raport został przygotowany, było to już 3074 TEU.

Konieczność podjęcia prac pogłębiarskich została już wcześniej zasygnalizowana w raporcie NIK Warunki Rozwoju Portów Morskich z 2011 roku, na który powołują się twórcy programu, wskazującym, że infrastruktura dostępowa do portów od strony morza nie ma właściwych parametrów eksploatacyjnych, w szczególności dotyczących głębokości i szerokości torów podejściowych ${ }^{10}$.

2. Ustawa z dnia 20 grudnia 1996 r. o portach i przystaniach morskich, Dz. U. 1997 nr 9, poz. 44.

3. https://www.msp.gov.pl/download/2/11645/strategiarozwojuportowmorskichdo2015roku.pdf [dostęp: 21.08.2017].

4. Wykaz prac legislacyjnych i programowych Rady Ministrów https://bip.kprm.gov.pl/kpr/form/r2036,Projekt-uchwaly-Rady-Ministrow-w-sprawie-przyjecia-Programu-rozwoju-polskich-por.html [dostęp: 21.08.2017].

5. Program rozwoju polskich portów morskich do 2020 roku (z perspektywq do 2030 roku), Warszawa 2013, http://docplayer.pl/63763-Program-rozwoju-polskich-portow-morskich-do-roku-2020-z-perspektywa-do-2030-roku.html [dostęp: 29.08.2017].

6. Ibidem.

7. Ibidem.

8. Review of Maritime Transport 2012, http://unctad.org/en/PublicationsLibrary/rmt2012_en.pdf [dostęp: 10.08.2017] .

9. Twenty-foot equivalent unit - jednostka używana do określenia pojemności statku, jest odpowiednikiem objętości jednego kontenera o długości 20 stóp.

10. Informacja o wynikach kontroli NIK „Warunki rozwoju portów morskich”, NIK, Warszawa 2011, Nr ewid. $177 / 2011 / \mathrm{P} / 11 / 063 / \mathrm{KIN}, \mathrm{s} .23$. 
Parametry stanowiące punkt odniesienia dla raportu NIK zostały wskazane w rozporządzeniu z dnia 9 grudnia 2002 roku Ministra Infrastruktury w sprawie określenia obiektów, urządzeń i instalacji wchodzącej w skład infrastruktury zapewniającej dostęp do portów o podstawowym znaczeniu dla gospodarki narodowej ${ }^{11}$. Aktualnie obowiązującym aktem prawnym w tej materii jest rozporządzenie Ministra Infrastruktury i Rozwoju z dnia 7 maja 2015 roku o tożsamej nazwie ${ }^{12}$, które w swojej treści jeszcze bardziej zwiększa wymogi w tym zakresie. W szczególności dotyczy to głębokości technicznej torów podejściowych, która wzrosła w przypadku Gdańskiego Portu Północ z 17,0 m do 17,5 m oraz dla wejścia głównego do Portu Gdynia z 14,1 m do 14,5 m. W przypadku toru wodnego Świnoujście-Szczecin łączącego oba porty, głębokość techniczną 13,0 m, utrzymaną na odcinku od km 3,1 do 3,3 w aktualnie obowiązującym rozporządzeniu postanowiono rozciagnąc na odcinku szerokości 5,28 km. Dla portów innych niż porty o podstawowym znaczeniu dla gospodarki narodowej parametry infrastruktury dostępowej określają zarządzenia właściwych Dyrektorów Urzędów Morskich, wydawane na podstawie ustawy z dnia 21 marca 1991 roku o obszarach morskich Rzeczypospolitej Polskiej i administracji morskiej.

Szacunkowa wartość największych inwestycji w zakresie infrastruktury dostępowej do portów na lata 2014-2017 można odczytać z Dokumentu implementacyjnego do strategii rozwoju transportu do 2020 roku (z perspektywa do 2030 roku] ${ }^{13}$. W poniższej tabeli zaprezentowana została ta część projektów, której wykonanie wymagać będzie przeprowadzenia prac pogłębiarskich.

Tabela 1. Projekty inwestycyjne przewidziane do realizacji na lata 2014-2020, wymagające prac pogłębiarskich

\begin{tabular}{|c|l|l|c|l|}
\hline Lp. & \multicolumn{1}{|c|}{ Nazwa projektu } & \multicolumn{1}{|c|}{ Beneficjent } & $\begin{array}{c}\text { Koszt całkowity } \\
\text { (mln zł) }\end{array}$ & \multicolumn{1}{|c|}{$\begin{array}{c}\text { Źródło } \\
\text { finansowania }\end{array}$} \\
\hline 1. & $\begin{array}{l}\text { Modernizacja wejścia do portu } \\
\text { wewnętrznego (w Gdańsku). Etap III }\end{array}$ & Urząd Morski w Gdyni & 150,00 & $\begin{array}{l}\text { fundusze strukturalne, } \\
\text { środki krajowe }\end{array}$ \\
\hline 2. & $\begin{array}{l}\text { Modernizacja toru wodnego } \\
\text { Świnoujście-Szczecin do głębokości } \\
\text { 12,5m }\end{array}$ & $\begin{array}{l}\text { Urząd Morski } \\
\text { w Szczecinie }\end{array}$ & 1384,98 & $\begin{array}{l}\text { fundusze strukturalne, } \\
\text { środki krajowe }\end{array}$ \\
\hline 3. & $\begin{array}{l}\text { Modernizacja toru wodnego do Portu } \\
\text { Północnego }\end{array}$ & Urząd Morski w Gdyni & 660,00 & $\begin{array}{l}\text { fundusze strukturalne, } \\
\text { środki krajowe }\end{array}$ \\
\hline 4. & $\begin{array}{l}\text { Modernizacja toru wodnego, rozbudowa } \\
\text { nabrzeży oraz poprawa warunków } \\
\text { żeglugi w Porcie Wewnętrznym } \\
\text { w Gdańsku }\end{array}$ & $\begin{array}{l}\text { Zarzad Morskiego } \\
\text { Portu Gdańsk S.A. }\end{array}$ & 54,00 & CEF ${ }^{14}$ \\
\hline 5. & $\begin{array}{l}\text { Poprawa dostępu do portu w Szczecinie } \\
\text { w rejonie Kanału Dębickiego }\end{array}$ & ZMPSIŚ S.A & 200,00 & $\begin{array}{l}\text { fundusze strukturalne, } \\
\text { środki krajowe }\end{array}$ \\
\hline
\end{tabular}

11. Rozporządzenie Ministra Infrastruktury z dnia 9 grudnia 2002 r. w sprawie określenia obiektów, urządzeń i instalacji wchodzacych w skład infrastruktury zapewniajacej dostęp do portu o podstawowym znaczeniu dla gospodarki narodowej Dz. U. $2003 \mathrm{nr} 4$ poz. 41.

12. Rozporządzenie Ministra Infrastruktury i Rozwoju z dnia 7 maja 2015 r. w sprawie określenia obiektów, urządzeń i instalacji wchodzących w skład infrastruktury zapewniającej dostęp do portu o podstawowym znaczeniu dla gospodarki narodowej Dz. U. $2015 \mathrm{nr}$ 0, poz. 733.

13. Dokument implementacyjny do strategii rozwoju transportu do 2020 roku (z perspektywq do 2030 roku), Warszawa 2014, https://www.mr.gov.pl/strony/zadania/fundusze-europejskie/dokument-implementacyjny-do-strategii-rozwoju-transportu/ [dostęp: 17.10.2017].

14. Connecting Europe Facility - instrument finansowy Unii Europejskie, zastępujacy program TEN-T, wspierający rozwój w obszarach sieci transportowych, energetycznych oraz telekomunikacyjnych. 


\begin{tabular}{|c|c|c|c|c|}
\hline Lp. & Nazwa projektu & Beneficjent & $\begin{array}{l}\text { Koszt całkowity } \\
\text { (mln zł] }\end{array}$ & $\begin{array}{c}\text { Źródło } \\
\text { finansowania }\end{array}$ \\
\hline 6. & $\begin{array}{l}\text { Poprawa dostępu do portu w Szczecinie } \\
\text { w rejonie Basenu Kaszubskiego }\end{array}$ & ZMPSIŚ S.A. & 200,00 & $\begin{array}{l}\text { fundusze strukturalne, } \\
\text { środki krajowe }\end{array}$ \\
\hline ?. & $\begin{array}{l}\text { Pogłębienie toru podejściowego } \\
\text { i akwenów wewnętrznych Portu } \\
\text { Gdynia Etapy I-III }\end{array}$ & $\begin{array}{l}\text { ZMP Gdynia (Etap I), } \\
\text { Urząd Morski (Etap II), } \\
\text { ZMP Gdynia (Etap III) }\end{array}$ & 220,00 & $\begin{array}{l}\text { fundusze strukturalne, } \\
\text { środki krajowe }\end{array}$ \\
\hline 8. & $\begin{array}{l}\text { Przebudowa wejścia do portu } \\
\text { w Elblągu }\end{array}$ & Urząd Morski w Gdyni & 201,77 & $\begin{array}{l}\text { fundusze strukturalne, } \\
\text { środki krajowe }\end{array}$ \\
\hline 9. & Przebudowa wejścia do portu Darłowo & $\begin{array}{l}\text { Urząd Morski } \\
\text { w Słupsku }\end{array}$ & 220,00 & $\begin{array}{l}\text { fundusze strukturalne, } \\
\text { środki krajowe }\end{array}$ \\
\hline 10. & $\begin{array}{l}\text { Budowa obrotnicy dla statków } \\
\text { w Elblagu }\end{array}$ & $\begin{array}{l}\text { Gmina Miasto } \\
\text { Elbląg / Zarząd Portu } \\
\text { Morskiego Sp. z o.o. }\end{array}$ & 5,00 & $\begin{array}{l}\text { fundusze strukturalne, } \\
\text { środki krajowe }\end{array}$ \\
\hline 11. & Przebudowa wejścia do Portu Ustka & $\begin{array}{l}\text { Urzad Morski } \\
\text { w Słupsku }\end{array}$ & 205,00 & $\begin{array}{l}\text { fundusze strukturalne, } \\
\text { środki krajowe }\end{array}$ \\
\hline 12. & $\begin{array}{l}\text { Przebudowa wejścia południowego } \\
\text { do portu w Gdyni }\end{array}$ & Urzad Morski w Gdyni & 600,00 & $\begin{array}{l}\text { fundusze strukturalne, } \\
\text { środki krajowe }\end{array}$ \\
\hline \multicolumn{3}{|c|}{ Razem } & 4100,75 & \\
\hline
\end{tabular}

Oprac. własne na podstawie listy projektów morskich przedstawionych w Dokumencie implementacyjnym do strategii rozwoju transportu do 2020 roku (z perspektywq do 2030 roku)

\section{Tryb udzielenia zamówienia na prace pogłębiarskie}

W realiach polskich nie zdarza się, aby w przetargu na prace pogłębiarskie - w odróżnieniu od tradycyjnej inwestycji budowlanej - jako zamawiający występował podmiot prywatny. Obszary morskie, na których prace te moga być przeprowadzane, to tereny wód portowych oraz tory podejściowe stanowiące infrastrukturę dostępową do portów. Obszary te podlegają oddzielnej administracji, odpowiednio podmiotom zarządzającym portami (dla portów o podstawowym znaczeniu dla gospodarki narodowej będących jednoosobowymi spółkami skarbu Państwa) oraz Dyrektorom Urzędów Morskich.

Dyrektorzy Urzędów Morskich wykonują swoje kompetencje przy pomocy urzędu morskiego. Urząd ten jest państwowa jednostką budżetową i w związku z tym nie posiada osobowości prawnej, a wszystkie jego wydatki sa pokrywane bezpośrednio z budżetu państwa. Zakres tych kompetencji określa przede wszystkim art. 42 ustawy o obszarach morskich Rzeczpospolitej Polskiej i administracji morskiej z 21 marca 1991 roku. ${ }^{15}$ Najistotniejsze z punktu widzenia problematyki niniejszych rozważań są kwestie dotyczące budowy i utrzymania obiektów infrastruktury zapewniającej dostęp do portów i przystani morskich oraz powiązane z nimi sprawy związane z wyznaczaniem dróg morskich, kotwicowisk oraz badaniem ich żeglowności. Działając w oparciu o kompetencje ustawowe, urzędy morskie zlecają - zazwyczaj w formie przetargów nieograniczonych - prowadzenie prac czerpalnych na podległych im obszarach.

15. Ustawa z dnia 21 marca 1991 r. o obszarach morskich Rzeczypospolitej Polskiej i administracji morskiej. Dz. U. Nr 32, poz. 131, tekst jednolity Dz. U. z 2003 r., Nr 153, poz. 1502 
Ustawa o portach i przystaniach morskich ${ }^{16}$ określa z kolei, że przedmiotem działalności podmiotów zarządzających portami jest między innymi budowa, rozbudowa, utrzymanie i modernizacja infrastruktury portowej. Przez infrastrukturę portową rozumie się znajdujące się w granicach portu lub przystani morskiej akweny portowe oraz urzadzenia i instalacje portowe. Inwestycje te są finansowane ze środków podmiotu zarządzającego, pozyskiwanych z tytułu opłat za użytkowanie gruntów portowych, opłat portowych, przychodów z usług oraz wpływów z innych tytułów.

Zgodnie z art. 3 ustawy Prawo zamówień publicznych ${ }^{17}$ oba te podmioty są zobowiązane stosować procedury zamówień publicznych. Każdorazowo zamówienie takie jest publikowane w Biuletynie Zamówień Publicznych. W razie gdyby kwota zamówienia przekraczała wartość określoną w Rozporządzeniu Prezesa Rady Ministrów wydanym na podstawie art. 11 ust. 8 ustawy Prawo zamówień publicznych ${ }^{18}$, jego treść publikowana jest również w Dzienniku Urzędowym Unii Europejskiej. Aktualnie kwota dla robót budowlanych, której przekroczenie nakłada taki obowiązek, wynosi 5225000 euro.

\section{Formułowanie wymogów ubezpieczeniowych w dokumentacji przetargowej}

Podmioty przystępujące do procedury udzielenia zamówienia w trybie określonym ustawą Prawo zamówień publicznych powinny rozróżniać w kontekście formułowania wymogów ubezpieczeniowych dwa etapy: 1) składanie ofert oraz 2) okres realizacji kontraktu. Zgodnie z §1 ust. 1 pkt 11 Rozporządzenia Prezesa Rady Ministrów z dnia 19 lutego 2013 roku w sprawie rodzajów dokumentów, jakich może żądać zamawiający od wykonawcy, oraz form, w jakich te dokumenty mogạ być składane, ${ }^{19} \mathrm{~W}$ pierwszym etapie zamawiający ma prawo żądać przedstawienia dowodu opłacenia polisy OC związanej z przedmiotem kontraktu do arbitralnie ustalonej z góry sumy gwarancyjnej. Jak wskazuje orzecznictwo Krajowej Izby Odwoławczej, celem żądania polisy ubezpieczeniowej od wykonawcy jest jedynie ocena sytuacji ekonomicznej i finansowej, w jakiej się ten znajduje. Dokument ten nie ma służyć jako zabezpieczenie realizacji zamówienia. Celem przedłożenia polisy, podążając za wyznaczoną linią orzeczniczą Krajowej Izby Odwoławczej, jest tylko sprawdzenie zdolności poniesienia określonych kosztów celem uzyskania ubezpieczenia ${ }^{20}$. Stanowisko to zgodne jest ze wcześniejszym orzeczeniem Sądu Okręgowego we Wrocławiu, w którym sąd stwierdził, że celem przedłożenia polisy OC jest sprawdzenie zdolności wykonawcy do ubezpieczenia własnej działalności na żądana przez zamawiającego sumę i możliwość uzyskania ubezpieczenia. Ubezpieczyciel ma weryfikować w takich sytuacjach podmiot zamierzający zawrzeć umowę ubezpieczenia pod względem jego wiarygodności, uczciwości gospodarczej oraz możliwości zapłaty

16. Ustawa z dnia 20 grudnia 1996 r. o portach i przystaniach morskich. Dz. U. $1997 \mathrm{nr} 9$ poz. 44

17. Ustawa z dnia 29 stycznia 2004 r. Prawo zamówień publicznych. Dz. U. 2004 nr 19 poz. 177

18. Rozporządzenie Prezesa Rady Ministrów z dnia 23 grudnia 2013 r. w sprawie kwot wartości zamówień oraz konkursów, od których jest uzależniony obowiązek przekazywania ogłoszeń Urzędowi Publikacji Unii Europejskiej.

19. Rozporządzenie Prezesa Rady Ministrów z dnia 19 lutego 2013 r. w sprawie rodzajów dokumentów, jakich może żądać zamawiający od wykonawcy, oraz form, w jakich te dokumenty mogą być składane (Dz. U. 2013, poz. 231).

20. Zob. wyrok KIO z dnia 18 stycznia 2012 r. KIO/UZP 62/12. 
składek $^{21}$. Dotyczy to jednak tylko etapu składania ofert, natomiast wymóg posiadania właściwego ubezpieczenia OC przez wybranego wykonawcę dla wykonywania kontraktu powinien zostać sformułowany oddzielnie ${ }^{22}$.

Formułując w dokumentacji przetargowej wymagany zakres ubezpieczenia dla kontraktu na prace pogłębiarskie, należy mieć na względzie wyjątkowo specjalistyczny charakter prac oraz szczególna pozycję armatora wobec wierzycieli. Wskazane byłoby, aby zamawiający bardzo dokładnie rozważył, jakiego rodzaju ochrony oczekuje.

Zgodnie z Konwencją o ograniczeniu odpowiedzialności za roszczenia morskie ${ }^{23}$ (której Polska jest strona) właściciele statków morskich (w tym również w rozumieniu konwencji czarterujący, armatorzy oraz zarządzający statkiem morskim) mogą ograniczyć swoją odpowiedzialność wobec szeregu roszczeń związanych z ich eksploatacją. Uprawnienie to dotyczy także ubezpieczyciela odpowiedzialności z tytułu ryzyk objętych konwencja w takim samym zakresie jak ubezpieczajacego. Jak stanowi konwencja, niezależnie od podstawy odpowiedzialności, armator ma między innymi prawo do ograniczenia odpowiedzialności wobec:

- roszczeń z tytułu śmierci, uszkodzenia ciała lub uszkodzenia mienia (łạcznie z uszkodzeniem urządzeń portowych, basenów, dróg wodnych i oznakowań nawigacyjnych), które zdarzyły się na statku lub w bezpośrednim związku z jego eksploatacją albo akcjami ratowniczymi, oraz z tytułu szkód wynikłych w ich konsekwencji,

- roszczeń z tytułu innych szkód spowodowanych naruszeniem praw innych niż prawa wynikające z umów, powstałych w bezpośrednim związku z eksploatacja statku lub akcjami ratowniczymi,

- roszczeń z tytułu podniesienia, usunięcia, zniszczenia lub uczynienia nieszkodliwym statku, który zatonałł, stał się wrakiem, wszedł na mieliznę lub został porzucony wraz ze wszystkim, co znajduje się lub znajdowało na takim statku.

Przywileju tego armator może być pozbawiony jedynie w sytuacji, gdy szkoda została wyrzadzona jego własnym działaniem lub zaniedbaniem, popełnionym z zamiarem wyrządzenia szkody lub lekkomyślnie i ze świadomością, że szkoda może nastapić. Uprawnienie to dotyczy jednak tylko statków uprawiających żeglugę morską, zatem zwłaszcza mniejsze jednostki zarejestrowane w rejestrze żeglugi śródladowej nie będą nim objęte.

Kwota ograniczenia odpowiedzialności jest obliczana na podstawie tonażu statku, natomiast jednostką obliczeniowąjest SDR - Specjalne Prawa Ciagnnienia. Zgodnie z obowiązującą w polskim systemie prawnym od 8 czerwca 2015 roku zmianą do protokołu z 1996 roku zmieniającego konwencję o ograniczeniu odpowiedzialności dla jednostek o tonażu brutto ${ }^{24}$ nieprzekraczającym 2000 ton, pułap odpowiedzialności dla szkód z tytułu śmierci lub uszkodzenia ciała wynosi 2 mln SDR a dla pozostałych szkód $1 \mathrm{mln}$ SDR. Dla jednostek o większym tonażu limit odpowiedzialności oblicza się według zasad wskazanych w protokole.

21. Wyrok S0 we Wrocławiu z dnia 14 lipca 2011 r., X Ga 213/11.

22. Zob. wyrok KIO z dnia 18 stycznia 2012 r., KIO/UZP 62/12.

23. Konwencja o ograniczeniu odpowiedzialności za roszczenia morskie, 1976, sporządzona w Londynie dnia 19 listopada 1976 r. (Dz. U. 1986 nr 35, poz. 175), zmieniona Protokołem, sporządzonym w Londynie dnia 2 maja 1996 r. (Dz. U. 2012, poz. 146).

24. Gross tonnage (GT) - jednostka objętości służąca do pomiaru pojemności statku. 
Ryzyk objętych konwencją o ograniczeniu odpowiedzialności dotyczy obowiązek ubezpieczenia na mocy §102a Kodeksu morskiego ${ }^{25}$, stanowiącego implementację dyrektywy 2009/20/ WE Parlamentu Europejskiego ${ }^{26}$. Należy zatem mieć na uwadze, że granica odpowiedzialności wykonawcy prac jest określona przepisami ratyfikowanej umowy międzynarodowej i będzie miał on możliwość odwołania się do jej postanowień, uwalniając się od odpowiedzialności powyżej określonej kwoty. W przypadku próby odmiennego uregulowania tych postanowień umownie każdorazowo wymagana będzie zgoda ubezpieczyciela.

Jak wynika z dostępnej za pośrednictwem Biuletynu Informacji Publicznej dokumentacji przetargowej dotyczącej prac pogłębiarskich, oczekiwana ochrona ubezpieczeniowa każdorazowo będzie obejmować ubezpieczenie OC działalności gospodarczej, a sporadycznie również ubezpieczenie wszystkich ryzyk budowy na bazie warunków Contractors' All Risk ${ }^{27}$. W dalszej części niniejszego artykułu wskażę powody, dla których ubezpieczenia te nie mogą stanowić właściwego zabezpieczenia prac pogłębiarskich. Natomiast całkowicie poza sferą zainteresowania pozostaje kwestia ubezpieczeń morskich posiadanych przez flotę roboczą zaangażowaną na potrzeby inwestycji, pomimo że ich zakres może przynajmniej częściowo obejmować ryzyko związane z kontraktem.

\section{Najważniejsze produkty ubezpieczeniowe związane z przedmiotem działalności wykonawcy prac pogłębiarskich}

W dzisiejszych czasach praktycznie każdy podmiot prowadzący działalność gospodarczą zawiera ubezpieczenia zapewniające ochronę posiadanych środków trwałych oraz obejmujące jego odpowiedzialność cywilna. To, jaką konkretnie ochronę będzie posiadać przedsiębiorstwo, powinno zależeć od ryzyka związanego z prowadzeniem danego rodzaju działalności, z tym zastrzeżeniem, że istnieja pewne zagrożenia uniwersalne, na zaistnienie których narażony jest każdy podmiot. Do takich uniwersalnych zagrożeń z pewnością można zaliczyć ryzyko związane z własnością, posiadaniem lub użytkowaniem nieruchomości na potrzeby prowadzenia działalności gospodarczej czy zatrudnianiem pracowników. Z punktu widzenia wykonawcy prac pogłębiarskich szczególnie istotne - a także generujące największy koszt - jest jednak ryzyko związane z posiadaniem i użytkowaniem floty pływającej oraz prowadzeniem robót. Ten właśnie obszar powinien podlegać szczegółowej analizie podczas przystępowania do kontraktu.

\subsection{Ubezpieczenie odpowiedzialności cywilnej związanej z prowadzeniem działalności gospodarczej}

Przedmiotem ubezpieczenia jest w tym wypadku odpowiedzialność cywilna, odszkodowawcza ubezpieczonego za szkody osobowe lub rzeczowe wyrządzone osobom trzecim w związku z prowadzeniem działalności gospodarczej i posiadaniem mienia, w zakresie określonym w umowie. Analizując

25. Ustawa z dnia 18 września 2001 r. - Kodeks morski (Dz. U. 2001 nr 138, poz. 1545).

26. Dyrektywa Parlamentu Europejskiego i Rady 2009/20/WE z dnia 23 kwietnia 2009 r. w sprawie ubezpieczenia armatorów od roszczeń morskich.

27. Przeanalizowano zamówienia publiczne o wartości przekraczającej 30000 euro z lat 2013-2017 na rzecz UM Gdynia, UM Słupsk, ZMP Gdańsk S.A., ZMP Gdynia S.A. ZMP Świnoujście-Szczecin S.A. 
problematykę ubezpieczenia OC wykonawcy robót pogłębiarskich, w pierwszej kolejności należy skonfrontować zakres jego działalności z zakresem odpowiedzialności określonym ustawowo ${ }^{28}$. Następnie zaś zorientować się, w jakim zakresie możliwe jest pozyskanie przez niego ochrony.

Odpowiedzialność wobec osób trzecich oparta na zasadzie ryzyka wynika wprost z art. 435 k.c. ${ }^{29}$ dotyczącego szkody wyrządzonej przez przedsiębiorstwo wprawiane w ruch siłami przyrody. Przedsiębiorstwa budowlane podpadaja pod tę kategorię, jako że ich działalność bazuje na zmechanizowanym systemie wykonywania robót i wykorzystuje maszyny poruszane za pomoca sił przyrody.

Obiekt, na którym prowadzone są prace pogłębiarskie, stanowi - w myśl rozporządzenia Ministra Środowiska z dnia 20 kwietnia 2007 roku $^{30}$ - budowlę hydrotechniczną. Wykonawca budowlany od chwili protokolarnego przejęcia terenu budowy, w tym wypadku akwenu wodnego, aż do chwili oddania obiektu ponosi odpowiedzialność za szkody wynikłe na tym terenie na zasadach ogólnych (art. 652 k.c.).

W odniesieniu do mienia kontrahentów na terenie budowy, a więc wszelkiego rodzaju konstrukcji podwodnych (np. rurociagu) czy nabrzeży, zastosowanie będzie miał przepis artykułu 471 k.c., na podstawie którego wykonawca będzie odpowiadał ex contractu za nienależyte wykonanie swoich obowiązków związanych z zabezpieczeniem terenu budowy wraz ze znajdującymi się na nim obiektami budowlanymi, urządzeniami technicznymi, maszynami, urządzeniami czy materiałami oraz innym mieniem kontrahentów.

Na polskim rynku ubezpieczeniowym oferowane ubezpieczenia OC z tytułu prowadzenia działalności gospodarczej zasadniczo pokrywają te zdarzenia z zastrzeżeniem ograniczeń odpowiedzialności, do których moga należeć: wskazany w polisie zakres działalności, definicje zawarte w umowie (wypadek, szkoda), zakres podmiotowy ubezpieczenia (bezpośrednio poszkodowani, pośrednio poszkodowani], sumy gwarancyjne i podlimity, stosowanie franszyz oraz wyłączenia zakresowe. To właśnie w obszarze wyłączeń zakresowych praktycznie we wszystkich dostępnych na rynku warunkach ubezpieczenia albo całkowicie wyłączone są szkody związane z posiadaniem, kierowaniem, używaniem jednostek pływających, albo też wskazane jest, że pokrycie takie jest zapewniane przez inne ubezpieczenia (w domyśle chodzi o ubezpieczenia morskie) ${ }^{31}$. Warunki ubezpieczenia dostępne na polskim rynku nie przewidują, że jednostki pływające mogą być używane w działalności gospodarczej innej niż uprawianie żeglugi, w związku z tym w razie braku zawarcia w umowie szczególnych postanowień obejmujących ten obszar działalności (oraz zorganizowania odpowiedniej reasekuracji] występować będzie luka w pokryciu ubezpieczeniowym

28. Główny wykonawca jest jedynym podmiotem spośród uczestników procesu budowlanego którego odpowiedzialność jest regulowana przepisami Kodeksu cywilnego, odpowiedzialność pozostałych uczestników tj. inwestora, inspektora nadzoru inwestorskiego, projektanta, kierownika budowy lub robót reguluje prawo budowlane, zob. ustawa z dnia ? lipca 1994 r. - Prawo budowlane (Dz. U. 1994 nr 89, poz. 414).

29. Ustawa z dnia 23 kwietnia 1964 r. - Kodeks cywilny (Dz. U. 1964 nr 16, poz. 93).

30. Zob. rozporządzenie Ministra Środowiska z dnia 20 kwietnia 2007 r. w sprawie warunków technicznych, jakim powinny odpowiadać budowle hydrotechniczne i ich usytuowanie (Dz. U. 2007 nr 86, poz. 579).

31. Por. Ogólne warunki ubezpieczenia odpowiedzialności cywilnej z tytułu prowadzonej działalności gospodarczej oraz posiadania rzeczy, AIG Europe Limited Spółka z ograniczoną odpowiedzialnością, oddział w Polsce, mające zastosowanie do umów ubezpieczenia zawartych po 1 stycznia 2016 r. lub Ogólne warunki ubezpieczenia odpowiedzialności cywilnej z tytułu prowadzenia działalności i posiadania mienia obowiązujące od dnia 1 marca 2016 r. - WARTA-C1076. 
obejmująca wszystkie ewentualne szkody powstałe w związku z prowadzeniem prac pogłębiarskich. Standardowe OC działalności dotyczyć będzie jedynie działalności lądowej takiego przedsiębiorcy, co z punktu widzenia ryzyk związanych z realizacją kontraktu jest niewystarczające, jako że całość prac wykonywana jest na wodzie przez specjalistyczną flotę pływająca ${ }^{32}$. Z tego powodu zamawiający powinien być zainteresowany ustaleniem zakresu posiadanej przez wykonawcę ochrony w zarówno w ramach OC działalności, jak i w ramach OC armatora.

\subsection{Ubezpieczenia odpowiedzialności cywilnej armatora}

Ubezpieczenie OC armatora należy do ubezpieczeń morskich, znajdujących swoje uregulowanie w tytule VIII Kodeksu morskiego w art. od 292 do 338, co oznacza, że polski ustawodawca uznał je za integralną część prawa morskiego. Potwierdza to również art. 820 k.c., który stanowi, że przepisów Kodeksu cywilnego o umowie ubezpieczenia nie stosuje się do ubezpieczeń morskich. Znajdą one jedynie zastosowanie uzupełniające, na co pozwala art. 1 §2 k.m. Przepisy Kodeksu morskiego dotyczące umowy ubezpieczenia morskiego mają w przeważającej mierze charakter dyspozytywny (ius dispositivum), ponieważ nie zawierają one zakazu umownego uregulowania określonych w nim stosunków ${ }^{33}$. Do przepisów bezwzględnie obowiązujących (ius cogens) można zaliczyć przepisy o przedawnieniu roszczeń i o odpowiedzialności deliktowej ${ }^{34}$. Wymogi odnośnie minimalnego zakresu ubezpieczenia są określone w konwencjach międzynarodowych, których polska jest stroną. Do podstawowych regulacji należą konwencja o ograniczeniu odpowiedzialności za roszczenia morskie, konwencja bunkrowa ${ }^{35}$ konwencja olejowa ${ }^{36}$ czy konwencja o usuwaniu wraków ${ }^{37}$. Konkretne parametry wymaganego zabezpieczenia finansowego posiadanego przez armatorów będą zależeć od rodzaju statku, tonażu czy obszaru żeglugi, natomiast szczegółowe postanowienia dotyczące przesłanek odpowiedzialności oraz jej zakresu znajdować się będa w treści warunków instytutowych lub warunków klubowych (P\&l), a także w treści polis.

Najbardziej rozpowszechnionym na świecie sposobem ubezpieczenia w zakresie odpowiedzialności cywilnej armatora jest uczestnictwo w klubie armatorskim. Londyńskie stowarzyszenie International Group of P\&l Clubs zrzesza obecnie ok. 90\% światowego tonażu ${ }^{38}$. Kluby armatorskie

32. Do zasadniczych prac czerpalnych należy profilowanie skarp oraz pogłębianie dna morskiego. Odbywa się ono przy pomocy pogłębiarek łyżkowych, czerpakowych lub ssących w zależności od głębokości akwenu i rodzaju urobku. Elementem prac jest również deponowanie urobku na wskazane klapowiska, Najpowszechniejsze metody to stosowanie rur ciśnieniowych, rurociagów refulacyjnych lub składowanie urobku bezpośrednio na szalandy - specjalne jednostki pływajace wyposażone w klapy denne.

33. J. Łopuski, Prawo morskie. Tom II, Oficyna Wydawnicza Branta, Bydgoszcz-Toruń 2000.

34. Z. Brodecki, Prawo ubezpieczeń morskich, Wydawnictwo Prawnicze „Lex”, Sopot 1999, s. 59.

35. Międzynarodowa Konwencja o odpowiedzialności cywilnej za szkody spowodowane zanieczyszczeniem olejami bunkrowymi, przyjęta przez Międzynarodową Organizację Morską w Londynie w dniu 23 marca 2001 r. (Dz. U. $2006 \mathrm{nr}$ 148, poz. 939).

36. Międzynarodowa Konwencja o zapobieganiu zanieczyszczaniu morza przez statki, 1973, sporządzona w Londynie dnia 2 listopada 1973 r. wraz z załącznikami I, II, III, IV, i V, oraz Protokół z 1978 r. dotyczący tej konwencji, wraz z załącznikiem I, sporządzony w Londynie dnia 17 lutego 1978 r. (Dz. U. 1987 nr 17, poz. 101).

37. Nairobi International Convention on the Removal of Wrecks, przyjęta w 2007 r., weszła w życie w 2015 r. po ratyfikowaniu jej przez Danię, dotychczas nieimplementowana do polskiego porządku prawnego.

38. https://www.igpandi.org/about [dostęp: 21.10.2017]. 
są organizacjami non profit i oferują swoim członkom ochronę ubezpieczeniową na zasadzie wzajemności. Członkowie klubów wpłacają na ten cel składki liczone od tonażu objętych ubezpieczeniem jednostek ${ }^{39}$. Standardowa ochrona udzielana na bazie ubezpieczenia klubowego jest bardzo szeroka i obejmie m.in. obrażenia, choroby i śmierć marynarzy oraz innych osób na statku, wydatki związane z repatriacją i zastępstwem, odszkodowania w związku z utratą zatrudnienia spowodowaną zniszczeniem statku, wydatki związane ze zmianą trasy, koszty związane z ratowaniem życia na morzu, szkody w rzeczach osobistych osób na statku, szkody kolizyjne w zakresie nieobjętym ubezpieczeniem casco, uszkodzenie mienia, koszty zanieczyszczenia, odpowiedzialność związana z operacjami holowania ${ }^{40}$. Pomimo ogromnego zaplecza finansowego w roku 1993 International Group of P\&l Clubs wprowadziło do obrotu pojęcie operacji specjalistycznych ${ }^{41}$ znajdujących obecnie powszechnie zastosowanie w warunkach klubowych i wyłączenie ich ze standardowej ochrony. Przyczynkiem do rozpoczęcia prac nad zdefiniowaniem tego ryzyka była wielka powódź, jaka miała miejsce w Chicago w 1992 roku. Lokalna firma pogłębiarska, Great Lakes Dredge and Dock Company, prowadząc prace nad wymianą filarów mostu Kinzie Street nad rzeką Chicago, w trakcie robót przebiła ścianę nieużywanego od lat tunelu pod rzeką, co spowodowało zalanie miasta oraz straty rzędu 1 miliarda dolarów ${ }^{42}$.

Kluby P\&l zdecydowały się wyłaczyć tego typu zdarzenia z ochrony ubezpieczeniowej, jako w swej istocie odmienne od tradycyjnego ryzyka morskiego związanego z nawigowaniem jednostką pływającą i tym samym nadmiernie obciążające koncepcję wzajemności, na bazie której funkcjonują kluby armatorskie. Każdorazowo wyłączenie to odnosi się do szkód powstałych podczas wykonywania operacji specjalistycznych i mających z nimi związek, a nie do szkód wynikających z samego wykorzystywania konkretnych jednostek pływających ${ }^{43}$. Wyraźna jest zatem linia podziału na tak zwane szkody morskie i szkody w związku z prowadzeniem prac specjalistycznych. Dla przykładu, uprawianie żeglugi jednostką do układania kabli na miejsce prac czy też nawet już przebywanie jednostki na miejscu prac objęte będzie ochroną ubezpieczeniowa pod warunkiem, że proces układania kabla nie jest w toku. Ponadto jeżeli szkoda zajdzie z przyczyny zewnętrznej, niezwiązanej bezpośrednio z wykonywaniem czynności mieszczącej się w definicji operacji specjalistycznych, ochrona nadal będzie zachowana. Odmiennie została tu jednak potraktowana kwestia udzielania ochrony w stosunku do załogi, a także ryzyka wycieku oleju z jednostki czy konieczności podniesienia wraku. Bez względu na związek przyczynowy z wykonywaniem przez armatora operacji specjalistycznych ochrona udzielana jest przez postanowienia szczególne dla szkód osobowych poniesionych przez załogę oraz inne osoby na statku, podniesienia wraku oraz zanieczyszczenia olejowego wywołanego przez jednostkę. Postanowienia te nie dotycza jednak osób nieprzebywających na pokładzie, przewożonego ładunku czy szkód środowiskowych innych niż wyciek oleju ze statku.

39. Zob. International Group Agreement 2013, https://static.mycoracle.com/igpi_website/media/article_attachments/IGA2013.pdf [dostęp: 11.08.2017].

40. The Shipowner's Club, Club Rules 2017.

41. "Specialist operations shall include, but not be limited to dredging, blasting, pile driving, well stimulation, cable or pipe laying, construction, installation or maintenance work, core sampling, depositing of spoil, professional oil spill response and professional oil spill response training, but excluding fire fighting".

42. P.T. Reardon, The Loop's Great Chicago Flood, „Chicago Tribune”, http://www.chicagotribune.com/news/nationworld/politics/chi-chicagodays-flood-story-story.html, [dostęp: 02.04.2017].

43. Zob. Gard 2017 Rules, rule 59. 
Część klubów armatorskich odpowiedziała jednak na takie zapotrzebowanie i oferuje swoim członkom w ramach specjalnych klauzul możliwość rozszerzenia odpowiedzialności o ryzyko związane z odpowiedzialnością cywilną wobec osób trzecich podczas prowadzenia prac pogłębiarskich. Ochrona taka jednak nigdy nie obejmie szkód w samym obiekcie prac ani też błędów wykonawczych.

Ubezpieczenie OC armatora można zawrzeć także w zakładach ubezpieczeń w oparciu o tzw. klauzule instytutowe ${ }^{44}$. Standardowo stosowana klauzula OC armatora (Cl. 344) z 20 lipca 1987 roku ${ }^{45}$ obejmuje roszczenia jakiejkolwiek osoby trzeciej za szkodę powstałą w skutek:

- straty lub uszkodzenia jakiegokolwiek mienia / obiektu innego niż statek;

- próby lub rzeczywistego wydobycia wraku statku;

- manewrów wynikających z umowy holowniczej celem wejścia do portu lub wyjścia z portu lub manewrowania w jego granicach w trakcie zwykłej żeglugi w celach handlowych ( z wyłączeniem holowania kontraktowego);

- utraty życia, obrażeń ciała, choroby lub kosztów ratownictwa.

Ponadto pokrywa koszty:

- związane ze zmianą trasy wnikająca z konieczności zabrania chorych, rannych na ląd;

- podniesienia wraku;

- ochrony prawnej.

Klauzule instytutowe, inaczej niż ubezpieczenia na bazie warunków klubowych, nie rozróżniaja tego, czy statek jest w trakcie prowadzenia jakiejś działalności związanej z jego przeznaczeniem, czy nie. Tym samym szkody osób trzecich powstałe w trakcie i w związku z prowadzeniem prac czerpalnych zostana pokryte.

\subsection{Ubezpieczenie budowlano-montażowe (CAR)}

Ubezpieczenie wszystkich ryzyk budowy (Contractor's All Risks), tak typowe dla standardowych budów prowadzonych na lądzie, generalnie nie znajduje zastosowania przy zabezpieczeniu prac pogłębiarskich. Zdarza się jednak, że zamawiajacy wymaga, aby zostało ono zawarte, mimo iż w rzeczywistości będzie miało ono charakter pozorny.

Modelowy wzór ogólnych warunków ubezpieczenia CAR został przygotowany przez niemieckiego reasekuratora Munich $\operatorname{Re}^{46}$ i na jego podstawie zakłady ubezpieczeń opracowują treść ogólnych warunków umowy. Powoduje to, że występujące w nich różnice nie są znaczne i nie maja rozstrzygającego wpływu na rozważania podjęte w niniejszym artykule. Ubezpieczenie CAR jest ubezpieczeniem typu all risk, co oznacza, iż obejmuje swoją ochroną wszystkie ryzyka, z wyjątkiem tych wyłączonych postanowieniami umowy. Scharakteryzować można je jako ubezpieczenie modułowe, składające się z trzech sekcji, obejmujących swoim zakresem różne obszary ryzyka.

44. Tzw. klauzule instytutowe są opracowywane przez założony w $1884 \mathrm{r}$. Instytut Ubezpieczycieli Londyńskich, we współpracy z Lloyd’s Underwriting Association. Według Reference Book of Marine Insurance Clauses, $78^{\text {th }}$ edition, publikowanej cyklicznie przez wydawnictwo Witherby, aktualnie występuje 305 wzorcowych warunków ubezpieczenia dotyczących samych ryzyk morskich.

45. Reference Book of Marine Insurance Clauses, $68^{\text {th }}$ edition, Witherby Publishing, London 1996, s. 196-197.

46. https://www.imia.com/wp-content/uploads/2013/06/CAR_pol.pdf [dostęp: 15.08.2017]. 
Sekcja I obejmuje wszystkie szkody rzeczowo-finansowe powstałe w skutek nagłego, nieprzewidzianego wydarzenia w całym procesie inwestycyjnym, w okresie od momentu rozpoczęcia robót do dnia wystawienia świadectwa przejęcia. We wskazanym zakresie mieszczą się zatem szkody związane z działaniem siły wyższej (huragan, pożar, deszcz nawalny itp.), szkody kradzieżowe, akty wandalizmu, dewastacja mienia, osuwanie się ziemi, a także pewna część szkód typowo przypisywana do ryzyk OC - błąd ludzki, wadliwe wykonawstwo, wady materiałowe oraz wszelkie szkody powstałe w związku ze zbiegiem tych przyczyn. Przewaga ubezpieczenia CAR sekcja I nad ubezpieczeniem OC działalności jest znacznie szybsza wypłata odszkodowań. Wynika ona z tego, że w procesie likwidacji nie ma konieczności badania kwestii winy. Wypłata jest zależna od zajścia zdarzenia objętego polisa, nie zaś od ponoszenia odpowiedzialności w świetle przepisów prawa przez daną stronę kontraktu.

Sekcja Il obejmuje swoim zakresem odpowiedzialność cywilno-deliktowa podmiotów ubezpieczonych w związku z realizacją kontraktu. Ubezpieczenie to nie może być zawarte samodzielnie, zawsze konieczne będzie również zawarcie ubezpieczenia w ramach sekcji I. Ma ono chronić wykonawcę i inwestora przed roszczeniami osób postronnych od szkód osobowych i rzeczowych powstałych w związku z realizowaną inwestycją. W założeniu zakres ten powinien uzupełniać się z posiadanym przez wykonawcę ubezpieczeniem OC działalności. Z zakresu sekcji II standardowo wyłączone są niektóre szkody typowe dla OC działalności, tj. szkody wynikające z rażącego niedbalstwa ubezpieczonego, szkody dotyczące odpowiedzialności cywilnej kontraktowej, szkody w budowanym obiekcie, za które odpowiedzialny jest ubezpieczony, uszczerbek na zdrowiu pracowników, szkody środowiskowe czy czyste straty finansowe.

Sekcja III odnosi się do ryzyka utraty przyszłych korzyści przez zleceniodawcę z powodu ewentualnych opóźnień w oddaniu obiektu, które nastapiłyby w związku ze szkodą objętą ubezpieczeniem w ramach sekcji l. Przedmiotem ubezpieczenia jest w tym wypadku spodziewany zysk z inwestycji wraz z kosztami stałymi, w określonym w umowie przedziale czasowym. Podobnie jak sekcja II, sekcja III nie może być włączona do umowy bez zawarcia ubezpieczenia w ramach sekcji l.

Zakresy ubezpieczeń funkcjonujacych w związku z realizacja kontraktu budowlanego moga się krzyżować, dlatego też strony przystępujące do jego realizacji powinny wspólnie negocjować wymagany dla kontraktu zakres ochrony, tak aby nie był on dublowany i aby uniknać niepotrzebnych kosztów. Poniższa tabela ilustruje zakres pokrycia zapewniany przez poszczególne produkty ubezpieczeniowe dla wybranych ryzyk związanych z realizacją typowej inwestycji budowlanej.

Tabela 2. Dostępny zakres pokrycia wybranych ryzyk dla budowy lądowej

\begin{tabular}{|l|l|l|l|l|}
\hline & \multicolumn{1}{|c|}{ Sekcja I CAR } & \multicolumn{1}{c|}{ Sekcja II CAR } & Sekcja III CAR & \multicolumn{1}{c|}{ OC działalności } \\
\hline Okres ubezpieczenia & \multicolumn{2}{|l|}{ okres ściśle związany z kontraktem } & $\begin{array}{l}\text { standardowo roczny } \\
\text { okres ochrony }\end{array}$ \\
\hline Ubezpieczone ryzyko & $\begin{array}{l}\text { roboty wskazane } \\
\text { w polisie }\end{array}$ & $\begin{array}{l}\text { ryzyko objęte } \\
\text { sekcją I }\end{array}$ & $\begin{array}{l}\text { zyzyko objęte } \\
\text { sekcją I }\end{array}$ & $\begin{array}{l}\text { zgłoszonym do ubez- } \\
\text { pieczenia przedmio- } \\
\text { tem działalności }\end{array}$ \\
\hline $\begin{array}{l}\text { Ubezpieczony } \\
\text { rzkody w przedmiocie } \\
\text { prac związane z wysta- } \\
\text { pieniem siły wyższej }\end{array}$ & $\begin{array}{l}\text { inwestor, wykonawca, podwykonawcy, inne podmioty } \\
\text { zaangażowane w kontrakt }\end{array}$ & $\begin{array}{l}\text { ubezpieczony } \\
\text { podmiot }\end{array}$ \\
\hline
\end{tabular}


Prace pogłębiarskie - analiza możliwości wykorzystania ubezpieczenia ...

\begin{tabular}{|c|c|c|c|c|}
\hline & Sekcja I CAR & Sekcja II CAR & Sekcja III CAR & OC działalności \\
\hline $\begin{array}{l}\text { Szkody kradzieżowe } \\
\text { w mieniu na obszarze } \\
\text { budowy }\end{array}$ & tak & nie & nie & $\begin{array}{l}\text { w ramach klauzuli } 00 \\
\text { przechowawcy dot. } \\
\text { mienia powierzonego }\end{array}$ \\
\hline Wadliwe wykonawstwo & tak & nie & nie & tak \\
\hline $\begin{array}{l}\text { Szkody ponoszone } \\
\text { przez osoby postronne } \\
\text { w zwiazku z realizacja } \\
\text { kontraktu }\end{array}$ & nie & tak & nie & tak \\
\hline $\begin{array}{l}\text { Szkody ponoszone } \\
\text { przez pracowników } \\
\text { ubezpieczonego }\end{array}$ & nie & nie & nie & tak \\
\hline $\begin{array}{l}\text { Szkody wynikajace } \\
\text { z rażącego niedbalstwa }\end{array}$ & nie & nie & nie & tak \\
\hline $\begin{array}{l}\text { Straty finansowe } \\
\text { zamawiającego }\end{array}$ & nie & nie & tak & tak \\
\hline $\begin{array}{l}\text { Szkody wynikajace } \\
\text { z ruchu pojazdów } \\
\text { niepodlegających } \\
\text { rejestracji }\end{array}$ & nie & \begin{tabular}{|l} 
wobec osób po- \\
stronnych nie- \\
zwiazzanych z rea- \\
lizacją kontraktu \\
\end{tabular} & nie & tak \\
\hline Szkody środowiskowe & nie & $\begin{array}{l}\text { dot. szkód osób } \\
\text { trzecich z wyła- } \\
\text { czeniem kar admi- } \\
\text { nistracyjnych }{ }^{47}\end{array}$ & nie & $\begin{array}{l}\text { dot. szkód osób trze- } \\
\text { cich z wyłaczeniem } \\
\text { kar administracyj- } \\
\text { nych }\end{array}$ \\
\hline
\end{tabular}

Oprac. własne na podstawie Ogólnych warunków ubezpieczenia budowy / montażu od wszystkich ryzyk z 15.12.1999 TUiR Warta S.A. oraz Ogólnych warunków ubezpieczenia Warta HDI - „Ubezpieczenie odpowiedzialności cywilnej $11 / 2008$

Jak wynika z powyższej analizy, możliwe jest objęcie ochroną ubezpieczeniową praktycznie pełnego przekroju ryzyk związanych z realizacją typowego kontraktu budowlanego. Znacznie skromniejsze sa jednak możliwości rynku w przypadku realizacji prac pogłębiarskich. Dla wszelkich kontraktów dotyczących prac hydrotechnicznych powszechnie stosowana jest tzw. klauzula ryzyk mokrych (Munich Re Special Endorsement for Wet Risks) ${ }^{48}$. Jest ona załączana do ubezpieczenia CAR w ramach sekcji I, tym samym ogranicza również zakres sekcji II i III. W myśl jej zapisów wyłączone z ochrony są:

- szkody w nabrzeżach lub innych miejscach postoju jednostek pływających, polegające na ich osiadaniu lub zatonięciu;

- szkody powstałe w wyniku naturalnego działania morza (przy czym za naturalne działanie uważa się stan morza mniejszy lub równy 8 stopniom w skali Beauforta);

- szkody polegające na zniszczeniu więcej niż 200 m nieukończonej kierownicy, grobli nabrzeżnej, wału przeciwsztormowego, wału przeciwpowodziowego, umocnień brzegu, dna, linii, ostróg brzegowych, falochronu bądź innej struktury portowej;

- szkody powstałe w skutek erozji gleby;

47. Szkody w środowisku naturalnym w rozumieniu §6 ust. 11 ustawy z dnia 13 kwietnia 2007 r. o zapobieganiu szkodom w środowisku i ich naprawie (koszty zapobiegawcze i naprawcze).

48. http://ahliasuransi.com/wp-content/uploads/2015/06/MR-Special-Endorsement-for-Wet-Risks.pdf [dostęp: 20.08.2017]. 
- szkody w robotach: bagrowanie, re-bagrowanie, prace czerpalne, refulacyjne lub zasypowe;

- straty lub zniszczenie materiału wypełniającego;

- koszty wymiany lub naprawy pali lub elementów ścian oporowych;

- koszty naprawy rozłączonych lub rozpiętych ścianek szczelnych oraz usunięcia przecieku lub infiltracji jakiegokolwiek materiału;

- koszty odtworzenia kształtów i wymiarów;

- koszty użycia jednostek i / lub sprzętu pływającego, jak również koszty odpowiedzialności związane z ich użyciem;

- koszty mobilizacji lub demobilizacji albo inne powstałe w wyniku utrzymywania w gotowości na odpowiednią pogodę sprzętu budowlanego dla konstrukcji offshore;

- szkody w układanych przewodach, kotwicach, łańcuchach i pławach;

- szkody powstałe na skutek uderzenia jednostki pływajacej;

- ryzyka morskie podlegające ubezpieczeniom morskim.

W kontraktach na prace pogłębiarskie praktycznie cały obszar ryzyka związany z ich realizacja jest zatem wyłączony z ubezpieczenia. Można to zilustrować poniższą tabelą.

Tabela 3. Dostępny zakres pokrycia wybranych ryzyk związanych z realizacją prac pogłębiarskich

\begin{tabular}{|c|c|c|c|c|c|}
\hline & Sekcja I CAR & $\begin{array}{l}\text { Sekcja II } \\
\text { CAR }\end{array}$ & $\begin{array}{l}\text { Sekcja III } \\
\text { CAR }\end{array}$ & OC działalności & OC armatora \\
\hline Okres ubezpieczenia & \multicolumn{3}{|c|}{ okres ściśle związany z kontraktem } & \multicolumn{2}{|c|}{ standardowo roczny okres ochrony } \\
\hline Ubezpieczone ryzyko & $\begin{array}{l}\text { roboty } \\
\text { wskazane } \\
\text { w polisie }\end{array}$ & $\begin{array}{l}\text { ryzyko } \\
\text { objęte } \\
\text { sekcją I }\end{array}$ & $\begin{array}{l}\text { ryzyko } \\
\text { objęte } \\
\text { sekcją I }\end{array}$ & $\begin{array}{l}\text { zgodne z PKD } \\
\text { lub zgłoszonym } \\
\text { do ubezpieczenia } \\
\text { przedmiotem } \\
\text { działalności firmy } \\
\end{array}$ & $\begin{array}{l}\text { odpowiedzialność } \\
\text { cywilna związana } \\
\text { z użytkowaniem } \\
\text { statku }\end{array}$ \\
\hline Ubezpieczony & \multicolumn{3}{|c|}{$\begin{array}{l}\text { inwestor, wykonawca, podwykonawcy, } \\
\text { inne podmioty zaangażowane w kontrakt }\end{array}$} & $\begin{array}{l}\text { ubezpieczony } \\
\text { podmiot }\end{array}$ & $\begin{array}{l}\text { właściciel / armator } \\
\text { statku }\end{array}$ \\
\hline $\begin{array}{l}\text { Szkody w przedmiocie } \\
\text { prac związane } \\
\text { z wystapieniem siły } \\
\text { wyższej }\end{array}$ & nie & nie & nie & nie & nie \\
\hline $\begin{array}{l}\text { Szkody kradzieżowe } \\
\text { w mieniu na obszarze } \\
\text { budowy }\end{array}$ & $\begin{array}{l}\text { tak } \\
\text { (mienie na na- } \\
\text { brzeżach, tere- } \\
\text { nie lądowym) }\end{array}$ & nie & nie & $\begin{array}{l}\text { w ramach klauzuli } \\
\text { OC przechowawcy } \\
\text { dot. mienia } \\
\text { powierzonego }\end{array}$ & $\begin{array}{l}\text { jednostki pływaja- } \\
\text { ce sa ubezpieczo- } \\
\text { ne w tym zakresie } \\
\text { w ramach ubezpie- } \\
\text { czenia H\&M }\end{array}$ \\
\hline Wadliwe wykonawstwo & nie & nie & nie & nie & nie \\
\hline $\begin{array}{l}\text { Szkody ponoszone } \\
\text { przez osoby postronne } \\
\text { w związku z realizacja } \\
\text { kontraktu }\end{array}$ & nie & nie & nie & nie & $\begin{array}{l}\text { tak } \\
\text { (w przypadku ube- } \\
\text { zpieczeń na bazie } \\
\text { warunków klubo- } \\
\text { wych konieczna de- } \\
\text { dykowana klauzula) }\end{array}$ \\
\hline $\begin{array}{l}\text { Szkody ponoszone } \\
\text { przez pracowników } \\
\text { ubezpieczonego }\end{array}$ & nie & nie & nie & tak & tak \\
\hline $\begin{array}{l}\text { Szkody wynikajace } \\
\text { z rażącego niedbalstwa }\end{array}$ & nie & nie & nie & tak & nie \\
\hline
\end{tabular}


Prace pogłębiarskie - analiza możliwości wykorzystania ubezpieczenia ...

\begin{tabular}{|l|l|l|l|l|l|}
\hline & Sekcja I CAR & $\begin{array}{c}\text { Sekcja II } \\
\text { CAR }\end{array}$ & $\begin{array}{c}\text { Sekcja III } \\
\text { CAR }\end{array}$ & OC działalności & OC armatora \\
\hline $\begin{array}{l}\text { Straty finansowe } \\
\text { zamawiającego }\end{array}$ & nie & nie & nie & nie & nie \\
\hline $\begin{array}{l}\text { Szkody wynikające } \\
\begin{array}{l}\text { z ruchu jednostek } \\
\text { pływających }\end{array}\end{array}$ & nie & nie & nie & nie & tak \\
\hline Szkody środowiskowe & nie & nie & nie & nie & tak \\
\hline
\end{tabular}

Oprac. własne na podstawie Ogólnych warunków ubezpieczenia budowy / montażu od wszystkich ryzyk z 15.12.1999, Ogólnych warunków ubezpieczenia Warta HDI - „Ubezpieczenie odpowiedzialności cywilnej 11/2008”, Institute Protection and Indemnity Clauses Hulls - Time 20/7/87 (Clause 344) oraz The Shipowner's Club Rules 2017

Mając na uwadze, że cały zakres prac związany z prowadzeniem robót pogłębiarskich odbywa się na wodzie przy wykorzystaniu specjalistycznych jednostek pływających, łatwo zaobserwować nieadekwatność do potrzeb tej gałęzi budownictwa znacznej części produktów ubezpieczeniowych - typowo wykorzystywanych przy budowie lądowej.

Jak wynika z analizy przedstawionej w tabeli powyżej, dostępne na rynku ubezpieczenia nie obejmą szkód w przedmiocie robót wynikłych z dowolnej przyczyny. Dotyczyć będzie to zarówno wadliwego wykonawstwa, jak i wystapienia siły wyższej. Ryzyko zniszczenia mienia otaczajacego teren budowy lub mienia osób trzecich jest znaczne z tego względu, że obszar prac nie jest zamkniętym placem. Szczególnie na wodach portowych każda jednostka może przepłyną́ w bezpośrednim sąsiedztwie robót czerpalnych. Ubezpieczenie OC działalności nie będzie miało zastosowania do tego typu szkód, jako iż wynikać będą one z użycia jednostki pływającej. Szkody zostana pokryte z ubezpieczenia OC armatora, a częściowo również z H\&M49. Armator będzie miał jednak prawo, w myśl przepisów konwencji, do kwotowego ograniczenia swojej odpowiedzialności.

Ubezpieczenie CAR znajduje zastosowanie jedynie w kontraktach, dla których prace pogłębiarskie stanowią tylko część robót, jak na przykład budowa obiektów inżynierii wodnej. Należy jednak mieć wówczas na uwadze, że prawidłowo ustalona suma ubezpieczenia nie powinna obejmować wartości robót pogłębiarskich.

\section{Podsumowanie}

Konieczność przeprowadzania prac pogłębiarskich jest na stałe wpisana w działalność portów i przystani morskich. Zarówno bieżące utrzymanie głębokości torów wodnych jak i znaczna części inwestycji hydrotechnicznych wymaga zaangażowania specjalistycznej floty pływającej do wybrania urobku z dna. Niniejszy tekst opisuje problematykę możliwości wykorzystania ubezpieczenia jako narzędzia zabezpieczenia interesów stron kontraktu, w swoich rozważaniach nie poruszałem natomiast kwestii gwarancji, traktując je jako odrębne zagadnienie.

Z przeanalizowanego przeze mnie zakresu ubezpieczeń dostępnych dla tego rodzaju prac wynika, że istnieje pewna luka w możliwej do uzyskania ochronie ubezpieczeniowej. Odpowiedzialność

49. Ubezpieczenie Hull \& Machinery standardowo pokrywa do 3/4 odpowiedzialności za zderzenia z innymi statkami, por. Institute Time Clauses - Hulls 01/11/1995 (Clause 280), ubezpieczenia OC armatora obejmuja swoim zakresem nadwyżkę odpowiedzialności finansowej niepokrytej przez ubezpieczenie H\&M. 
za ten stan rzeczy przypisywałbym konstrukcji określonych produktów ubezpieczeniowych. Z jednej strony ubezpieczenia budowy tzw. CAR podobnie jak i ubezpieczenie OC działalności gospodarczej, nie obejmują swoim zakresem ryzyk związanych z użytkowaniem jednostek pływających, natomiast dla wszystkich inwestycji hydrotechnicznych stosują „klauzulę specjalną dla ryzyk mokrych", z drugiej zaś strony ubezpieczenia morskie swoim zakresem obejmą tylko szkody wyrzadzone przez jednostkę pływającą i również nie obejmą przedmiotu prac ani procesu ich realizacji.

Pożądana ochrona ubezpieczeniowa jest możliwa do uzyskania w ograniczonym zakresie na bazie ubezpieczeń morskich (szkody os. trzecich, szkody kolizyjne, szkody w mieniu otaczającym). Należy jednak pamiętać, że zgodnie z konwencją o ograniczeniu odpowiedzialności, której Polska jest sygnatariuszem, odpowiedzialność armatora podlega ograniczeniu do sumy wskazanej w jej treści zależnej od tonażu danej jednostki pływającej. Ryzykiem nieubezpieczalnym, a przynajmniej w większym zakresie, pozostaja szkody w samym obiekcie prac, tj. w pogłębianym dnie (wadliwe wykonawstwo, siła wyższa]. Oczywiście możliwe jest, że jakiś zakład ubezpieczeń przyjmie to ryzyko na swój zachowek, jednak należy liczyć się z tym że granica jego odpowiedzialności będzie na niskim poziomie. Możliwa do wyobrażenia jest sytuacja gdy szczególnie silny sztorm lub przypływ nanoszący namuł zniszczy pracę i wówczas wobec braku możliwości właściwego zabezpieczenia stron ubezpieczeniem, konieczność naprawy spoczywać będzie na wykonawcy. Prace te zwyczajowo wykonywane sa jednak odcinkami i wykonawca jest w ryzyku do momentu przekazania odcinka. Problem wadliwego wykonawstwa jest raczej czysto teoretyczny, aktualna technologia powoduje że wszystko odbywa się w sposób kontrolowany (koparki są programowane po przeprowadzeniu wstępnych sondaży) i na tyle wolno że nawet gdyby zaczęto wybierać urobek w złym miejscu możliwa jest bieżąca korekta.

\section{Wykaz źródeł}

\section{Akty prawne}

Dyrektywa Parlamentu Europejskiego i Rady 2009/20/WE z dnia 23 kwietnia 2009 r. w sprawie ubezpieczenia armatorów od roszczeń morskich.

Konwencja o ograniczeniu odpowiedzialności za roszczenia morskie, 1976, sporządzona w Londynie dnia 19 listopada 1976 r. (Dz. U. 1986 nr 35, poz. 175), zmieniona Protokołem, sporzadzonym w Londynie dnia 2 maja 1996 r. (Dz. U. 2012, poz. 146).

Międzynarodowa Konwencja o odpowiedzialności cywilnej za szkody spowodowane zanieczyszczeniem olejami bunkrowymi, przyjęta przez Międzynarodową Organizację Morską w Londynie w dniu 23 marca 2001 r. (Dz. U. 2006 nr 148, poz. 939).

Międzynarodowa Konwencja o zapobieganiu zanieczyszczaniu morza przez statki, 1973, sporządzona w Londynie dnia 2 listopada 1973 r. wraz z załącznikami I, II, III, IV, i V, oraz Protokół z 1978 r. dotyczący tej konwencji, wraz z załącznikiem I, sporządzony w Londynie dnia 17 lutego 1978 r. (Dz. U. 1987 nr 17, poz. 101).

Nairobi 2007 International Convention on the Removal of Wrecks.

Rozporządzenie Ministra Infrastruktury z dnia 9 grudnia 2002 r. w sprawie określenia obiektów, urządzeń i instalacji wchodzących w skład infrastruktury zapewniającej dostęp do portu o podstawowym znaczeniu dla gospodarki narodowej (Dz. U. $2003 \mathrm{nr}$ 4, poz. 41). 
Rozporządzenie Ministra Środowiska z dnia 20 kwietnia 2007 r. w sprawie warunków technicznych, jakim powinny odpowiadać budowle hydrotechniczne i ich usytuowanie (Dz. U. 2007 nr 86, poz. 579).

Rozporządzenie Prezesa Rady Ministrów z dnia 23 grudnia 2013 r. w sprawie kwot wartości zamówień oraz konkursów, od których jest uzależniony obowiązek przekazywania ogłoszeń Urzędowi Publikacji Unii Europejskiej.

Rozporzadzenie Prezesa Rady Ministrów z dnia 19 lutego 2013 r. w sprawie rodzajów dokumentów, jakich może żądać zamawiający od wykonawcy, oraz form, w jakich te dokumenty mogą być składane (Dz. U. 2013, poz. 231)

Uchwała Rady Ministrów Nr 33/2015 z dnia 17 marca 2015 r. w sprawie Polityki morskiej Rzeczypospolitej Polskiej do roku 2020 (z perspektywą do 2030 roku).

Uchwała Rady Ministrów Nr 292/2007 z dnia 13 listopada 2007 r. w sprawie przyjęcia „Strategii rozwoju portów morskich do 2015 roku".

Ustawa z dnia 20 grudnia 1996 r. o portach i przystaniach morskich (Dz. U. 1997 nr 9, poz. 44).

Ustawa z dnia 23 kwietnia 1964 r. - Kodeks cywilny (Dz. U. 1964 nr 16, poz. 93).

Ustawa z dnia $?$ lipca 1994 r. - Prawo budowlane (Dz. U. 1994 nr 89, poz. 414).

Ustawa z dnia 21 marca 1991 r. o obszarach morskich Rzeczypospolitej Polskiej i administracji morskiej (Dz. U. nr 32, poz. 131, tekst jednolity Dz. U. 2003 nr 153, poz. 1502).

Ustawa z dnia 29 stycznia 2004 r. - Prawo zamówień publicznych (Dz. U. 2004 nr 19, poz. 177). Ustawa z dnia 18 września 2001 r. - Kodeks morski (Dz. U. 2001 nr 138, poz. 1545).

Wyrok KIO z dnia 18 stycznia 2012 r. (KIO/UZP 62/12).

Wyrok SO we Wrocławiu z dnia 14 lipca 2011 r. (X Ga 213/11).

\section{Ogólne warunki ubezpieczenia}

Gard 2017 Rules.

Institute Protection and Indemnity Clauses Hulls - Time 20/7/87 (Clause 344).

Institute Time Clauses - Hulls 01/11/1995 (Clause 280).

Munich Re, Contractors' all risks.

Ogólne warunki ubezpieczenia budowy / montażu od wszystkich ryzyk z 15.12.1999, TUiR Warta S.A. Ogólne warunki ubezpieczenia odpowiedzialności cywilnej z tytułu prowadzonej działalności gospodarczej oraz posiadania rzeczy, AIG Europe Limited Spółka z ograniczoną odpowiedzialnością, oddział w Polsce, mające zastosowanie do umów ubezpieczenia zawartych po 1 stycznia 2016. Ogólne warunki ubezpieczenia odpowiedzialności cywilnej z tytułu prowadzenia działalności i posiadania mienia obowiązujace od dnia 1 marca 2016 roku - WARTA-C1076.

Ogólne warunki ubezpieczenia Warta HDI - „Ubezpieczenie odpowiedzialności cywilnej” 11/2008. The Shipowner's Club, Club Rules 201 .

\section{Pozostałe}

Brodecki Z., Prawo ubezpieczeń morskich, Wydawnictwo Prawnicze „Lex”, Sopot 1999.

Dokument implementacyjny do strategii rozwoju transportu do 2020 roku (z perspektywa do 2030 roku], Warszawa 2014, https://www.mr.gov.pl/strony/zadania/fundusze-europejskie/dokument-implementacyjny-do-strategii-rozwoju-transportu/ [dostęp: 17.10.2017]. 
Informacja o wynikach kontroli NIK „Warunki rozwoju portów morskich”, NIK, Warszawa 2011, Nr ewid. 177/2011/P/11/063/KIN.

International Group Agreement https://static.mycoracle.com/igpi_website/media/article_attachments/IGA2013.pdf [dostęp: 11.08.2017].

Łopuski J., Prawo morskie. Tom II, Oficyna Wydawnicza Branta, Bydgoszcz-Toruń 2000.

Polityka morska Rzeczypospolitej Polskiej do roku 2020 (z perspektywq do 2030 roku), Warszawa 2015, https://mgm.gov.pl/wp-content/uploads/2016/01/Polityka-morska-RzeczypospolitejPolskiej_uchw._Nr_33_RM_z_17_03_2015.pdf [dostęp: 10.08.2017].

Program rozwoju polskich portów morskich do 2020 roku (z perspektywa do 2030), Warszawa 2013, http://docplayer.pl/63763-Program-rozwoju-polskich-portow-morskich-do-roku-2020-z-perspektywa-do-2030-roku.html [dostęp: 29.08.2017].

Reardon P.T., The Loop's Great Chicago Flood, „Chicago Tribune”, http://www.chicagotribune.com/ news/nationworld/politics/chi-chicagodays-flood-story-story.html [dostęp: 02.04.2017].

Reference Book of Marine Insurance Clauses 68 ${ }^{\text {th }}$ edition, Witherby Publishing, London 1996.

Review of Maritime Transport 2012, http://unctad.org/en/PublicationsLibrary/rmt2012_en.pdf [dostęp: 10.08.2017].

Strategia rozwoju portów morskich do 2015 roku, https://www.msp.gov.pl/download/2/11645/ strategiarozwojuportowmorskichdo2015roku.pdf [dostęp: 21.08.2017].

Wykaz prac legislacyjnych i programowych Rady Ministrów, https://bip.kprm.gov.pl/kpr/form/ r2036,Projekt-uchwaly-Rady-Ministrow-w-sprawie-przyjecia-Programu-rozwoju-polskich-por. html [dostęp: 21.08.2017].

\section{Dredging works - analysis of the possibilities of using insurance as a tool to secure the interests of contracting parties}

One of the most important elements of maintaining the competitiveness of Polish ports is constant execution of projects that improve access to the harbor from the sea. Such projects include the modernization and deepening of waterways, the strengthening of their banks and the development of external breakwaters. Dredging works are a key element of each of these investments. They rely on hydraulic or mechanical ground cohesion, lifting it over the surface of the water and transporting the resulting material to the disposal site. These activities are carried out using a specialized floating fleet. From the point of view of insurance issues, this is a very interesting problem, combining maritime risks and the risks associated with carrying out a construction investment. The subject of discussion in this article is to determine the real range of insurance coverage, which may a contractor have, and an indication of the remaining gaps. The evaluation of the adequacy of available protection can be a prelude to work on creating the optimum insurance offer for these investments and can provide the knowledge base for the formulation of insurance requirements in the tender documentation.

Key words: dredging works, insurance, maritime insurance, builder's risk, public tender, waterways modernization, Polish ports.

BARTOSZ JANIK - doktorant, Kolegium Ekonomiczno-Społeczne, Szkoła Główna Handlowa w Warszawie; broker ubezpieczeniowy, Meritum Sp. z o.o. 